\title{
The 9th ProGEO Symposium, Chęciny, Poland, 2018-an Overview
}

\section{Ewa Głowniak ${ }^{1}$}

Published online: 28 November 2019

(C) The European Association for Conservation of the Geological Heritage 2019

\section{Introduction}

ProGEO's aims for the protection of geological heritage have been promoted in Poland since time of the 1st International Symposium on the Conservation of Geological Heritage held at Digne-les-Bains in France in 1991. Professor Zofia Alexandrowicz from Poland attended the Digne meeting and became one of the founder members of ProGEO, and later also a national member of the ProGEO Council and an exponent of its ideas in Poland and within the Central Europe regional group. Following this long connection with ProGEO and the contribution of Poland to the development and dissemination of the ProGEO ideas, it was a great honor and privilege to entrust we Polish geoconservationists, with organizing the 9th International ProGEO Symposium.

\section{The Symposium Organization}

The Symposium took place from June 25 to 28, 2018, in the European Centre of Geological Education in Chęciny, within the Świętokrzyskie Voivodship, Poland. It was held under the auspices of the Rector of the University of Warsaw, Prof. Dr. hab. Marcin Pałys; the regional government, represented by the Marshal of the Świętokrzyskie Voivodship, Dr. Adam Jarubas; the Mayor of the Checciny Town and Municipality, Mgr Eng. Robert Jaworski; and the international organizations, ProGEO (President, Professor José Brilha, Portugal), the IUGS International Commission on Geoheritage (Secretary-General, Dr. Kevin Page, England), and the IUCN WCPA Geoheritage Specialist Group (Chair,

This article is part of the Topical Collection on Geoheritage and Conservation: Modern Approaches and Applications Towards the 2030 Agenda, IX ProGEO Symposium, Poland, 25-28th June, 2018

Ewa Głowniak

eglownia@uw.edu.pl

1 Faculty of Geology, University of Warsaw, ul. Żwirki i Wigury 93, 02-089 Warsaw, Poland
Professor Kyung Sik Woo, Republic of Korea). The National Organizing Committee for the meeting was chaired by Dr. hab. Ewa Głowniak and consisted of representatives from the Faculty of Geology of the University of Warsaw (the main organizer and headquarters of the committee), the Institute of Nature Conservation of the Polish Academy of Science in Kraków, Kielce Geopark, and the Polish Geological Institute-National Research Institute.

The scientific program included 3 days of oral presentations (including plenary sessions), poster sessions, and two topical workshops. There were two field trips held, pre- and post-symposium, each of 2 days. Optional events included the Conference Dinner and a Cultural Event. The meeting also included the ProGEO General Assembly, open event to all ProGEO members. The conference's aims were to present recent achievements in the management of geoheritage and protected areas and its relationship with broader nature conservation policies, but also to consider the contribution of geoconservation to the UN sustainable development agenda. Two-volume proceedings of the Symposium were issued, including, respectively, the Programme and Abstract Book and the Field Guidebook.

\section{The Symposium Proceedings}

The Welcoming Ceremony (Fig. 1a) and addresses were presented by Dr. hab. Ewa Głowniak, the Chair of the Symposium; Prof. Dr. José Brilha, the outgoing President of ProGEO; Ms. Ilona Morżoł from the Polish National Commission for UNESCO; Mr. Michał Poros, the Head of the Centre of Geoeducation of the Kielce Geopark; Dr. Marcin Kos, the Deputy Director of the Świętokrzyski Branch of the Polish Geological Institute-National Research Institute; and Mr. Robert Jaworski, the Mayor of the Checiny Town and Municipality. Prof. Zofia Alexandrowicz - a member of the Honor Committee - could not personally be present, but sent a welcoming laudation. She remembered the 1st International Symposium on the Conservation of Geological 
Fig. 1 a Participants at the Welcoming Ceremony: (from right) José Brilha (President of ProGEO); Ewa Głowniak (Chair), Ilona Morżoł (Polish National Commission for UNESCO), Robert Jaworski (Mayor of the Chęciny Town and Municipality); Marcin Kos (Deputy Director of Świętokrzyski Branch of the Polish Geological InstituteNational Research Institute) and Michał Poros, the Head of the Centre of Geoeducation of the Kielce Geopark. b The young and senior researchers-

geoconservationists during the Workshop leaded by Dr. Paulo Pereira. $\mathbf{c}$ The authors presenting their posters. d Workshop in the Centre of Geoeducation in the Geopark Kielce. e Participants of the pre-symposium field trip in Kraków, with the Royal Wawel Castle visible at the background. f Participants of the postsymposium field trip in the Zachełmie geosite with the exposure of the post-Variscan unconformity visible at the background. g Celebrating the 10th Anniversary of the journal Geoheritage: Kevin Page (Editorin-Chief for Geoheritage) and Lovísa Ásbjörnsdóttir (Special Issue, Guest Editor) presenting the Special Issue for 8th ProGEO Symposium held in Reykjavik, in Iceland, 2015. h Gala Dinner in the Ethnographic Park in Tokarnia Village. Photographs by Małgorzata Bieńkowska-Wasiluk and Radosław Wasiluk (a-d and g), Ewa Głowniak (f), Marcin Stępień (h), and Jan Urban (e)
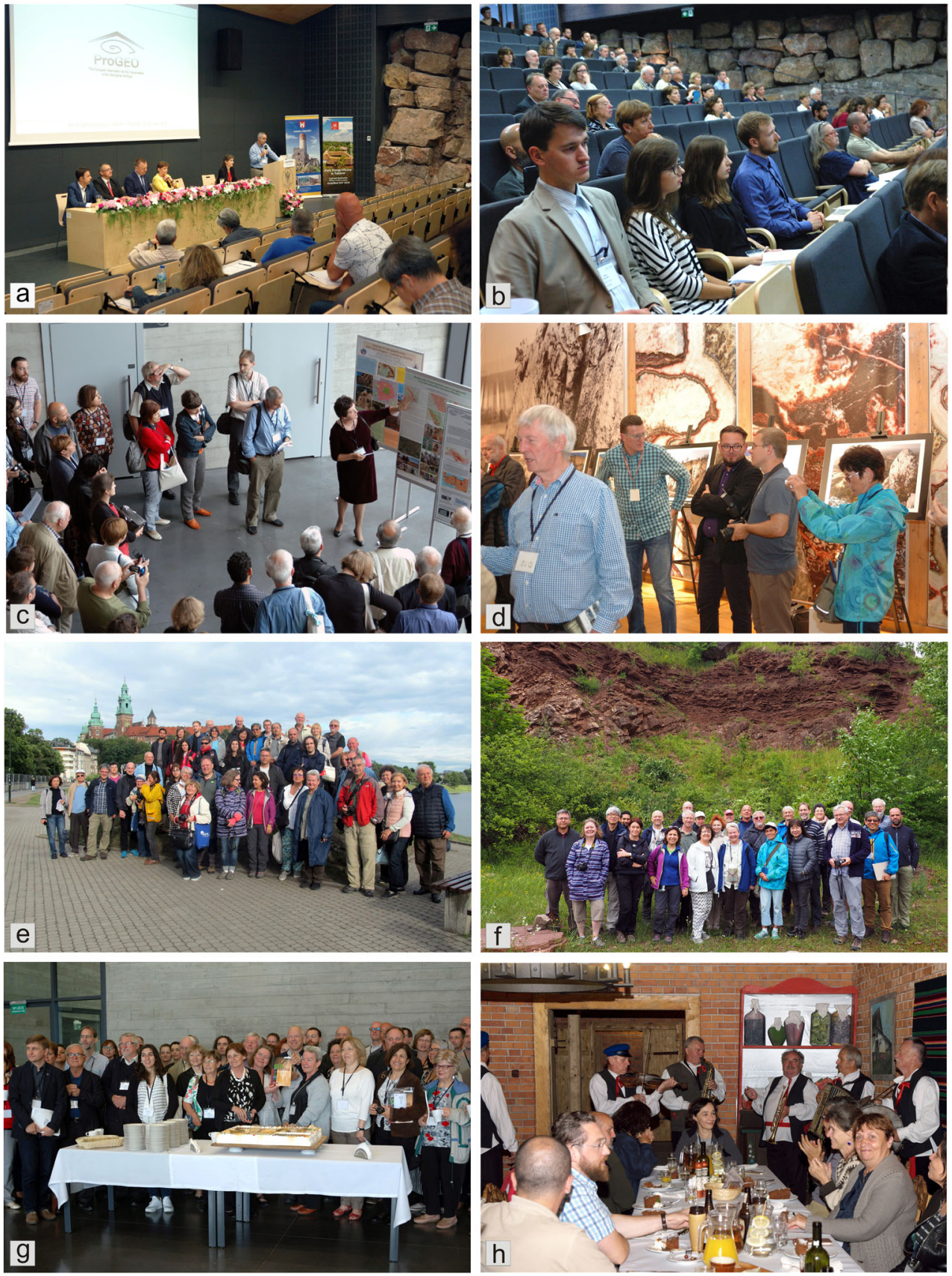

Heritage at Digne in France in which she participated, and, in that time, 1991, the atmosphere of enthusiasm for the idea of the protection of geological heritage. She reminded delegates of Poland's long tradition of protecting inanimate nature (geoconservation) and remembered the leading exponents of this idea in the years 1918-1939, the eminent university professors in geology, Stanisław Małkowski, Stefan Kozłowski, and Walery Goetl - the latter being one of the advisors on her thesis. Mr. Tymoteusz Wróblewski, an emeritus worker of the Świętokrzyski Branch of the Polish Geological InstituteNational Research Institute, was also present at the Welcoming Ceremony as an honor guest, a leading proponent for the protection of geoheritage of the Świetokrzyskie Region, author of a geoheritage map of this area, and the first to formulate the idea of establishing a Geological Landscape Park in the area in 1991.

The scientific program of the Symposium included two keynote lectures: the first presented by Dr. Juana Vegas from IGME, Madrid, entitled "Geoconservation from the public administrations: Fifty years of work at the Geological Survey of Spain (IGME)"; and the second by Professor Kyung Sik Woo from the Kangwon National University, Republic of Korea, entitled "Key Geoheritage Areas: A potential new programme in IUCN for geoheritage 
conservation". Dr. Vegas emphasized that IGME is the only Spanish public institution which develops statutory activity for geological and mining heritage protection and summarized the geoheritage achievements of the institution. Professor Woo discussed the new proposal of creating the Key Geoheritage Area (KGA) program, as a complementary project to the existing UNESCO World Heritage sites and UNESCO Global Geoparks programs. The concept has been developed under the auspices of the Geoheritage Specialist Group of the World Commission on Protected Areas of the International Union for Conservation of Nature, but has its origins in the concept of Global Geosites.

A total number of 52 oral presentations and 40 posters were presented during the scientific sessions, the authors of the latter presenting their achievements as short talks (Fig. 1c). The key themes of the meeting were:

- Geoconservation and landscape management

- Geoheritage and cultural heritage: mines, quarries, science, and communities

- Moveable geoheritage and science

- Geoconservation in protected areas and nature conservation strategies

- Geoconservation for science, education, and tourism

The most popular topics were that on the "Geoconservation for science, education, and tourism" and "Geoheritage and cultural heritage." The authors shared their experiences on the management and protecting of geosites and unique geological landscapes and bringing the concept of geoheritage and geoconservation to society and schools. Geoconservation and management strategies were discussed based on the case studies of some UNESCO Global Geoparks. The issue of ancient quarries was considered in terms of how to link communities to their geoheritage. A common theme was Geotourism, which some authors considered a vehicle for geoconservation. Several presentations dealt with modern techniques to promote cultural and geological heritage. Although contributions on "Movable geoheritage and science" were relatively few, one presentation demonstrated the potential to use decorative "rose-like" ex situ calcite for scientific purposes. Many presentations triggered active discussions.

The workshop on "Conservation, promotion and sustainable use of geological heritage on the urban areas - a case study from Kielce Geopark" took place in the Centre of Geoeducation of the Kielce Geopark (Fig. 1d) and was leaded by Mr. Michał Poros. The program included a sightseeing of the temporary exhibition devoted to the geoheritage and geoconservation in the Góry Świętokrzyskie Region and a guided tour of the permanent (educational) exhibition, which includes numerous interactive stands and dioramas with reconstructions of ancient life, accompanied by real specimens of rocks and fossils. The visitors were interested in the presented methods, educational games, and the techniques applied in work with the youngest enthusiasts of geology. The workshop "Geoheritage and geoconservation: junior researchers' perspectives" led by Dr. Paulo Pereira from the University of Minho, Portugal, was aimed at raising the awareness of young scientists about geoconservation and geological heritage, as well as the role of ProGEO at national and international levels. The workshop was conducted in the form of an open discussion and dialogue with experienced geoconservationists, with young researchers presenting and discussing novel ideas, approaches, and challenges, as well as the use of specific tools and techniques (Figs. 1b and 2).

The Gala Dinner and the Cultural Event were held at the Ethnographic Park in Tokarnia Village as an open-air party and a dinner in an old-style wooden granary with traditional Polish cuisine and drinks (Fig. 1h). The cultural program included an English-speaking-guided tour through the prettiest sights of the Ethnographic Park and a concert by the local folk group "Wierna Rzeka" (including traditional regional music, original instruments, and costumes). The Symposium also saw the celebration of the 10th Anniversary of the journal Geoheritage (Fig. 1g), with the generous presentation to the participants by Springer of an enormous and delicious cake, decorated with images from the journal's cover (Fig. 3).

During the two 2-day long field trips, delegates were guided through the top geosites and geological landscapes of Southern Poland, including the Góry Świętokrzyskie Region ("Holy Cross Mountains"), the Kraków Upland, and the Carpathian Foredeep with its salt mines to the south, and the Nida Region to the north. Amongst many other sites, the excursions included visits to two UNESCO World Heritage sites: Bochnia Medieval Salt Mine, with its Miocene salt rocks and salt tectonics of the southernmost Carpathian Foredeep

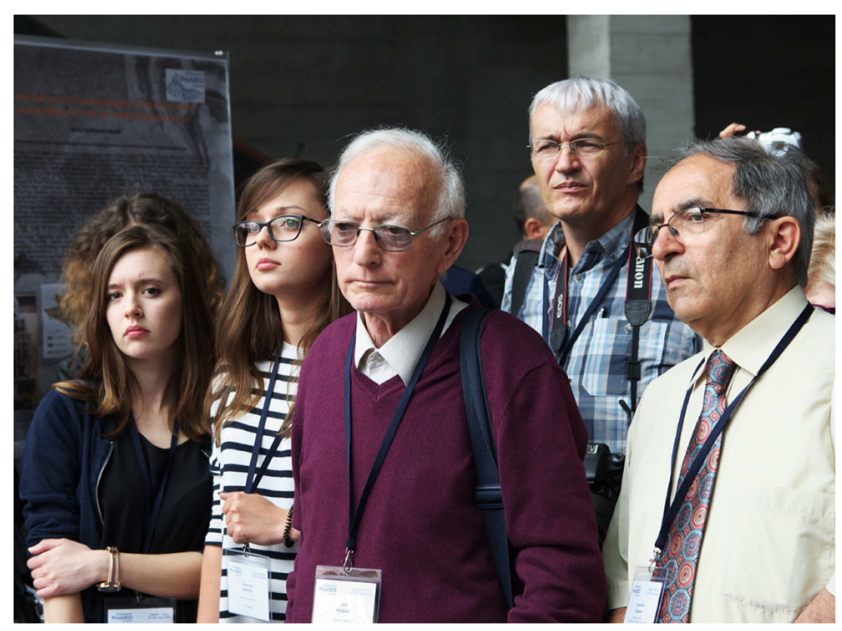

Fig. 2 The masters and the students: (from right) Prof. Nizamettin Kazanc1, Dr. Mari László, Prof. Afat Serjani, and the PhD students: Katarzyna Stróżyk and Anna Grabarczyk. Photograph by Małgorzata Bieńkowska-Wasiluk and Radosław Wasiluk 


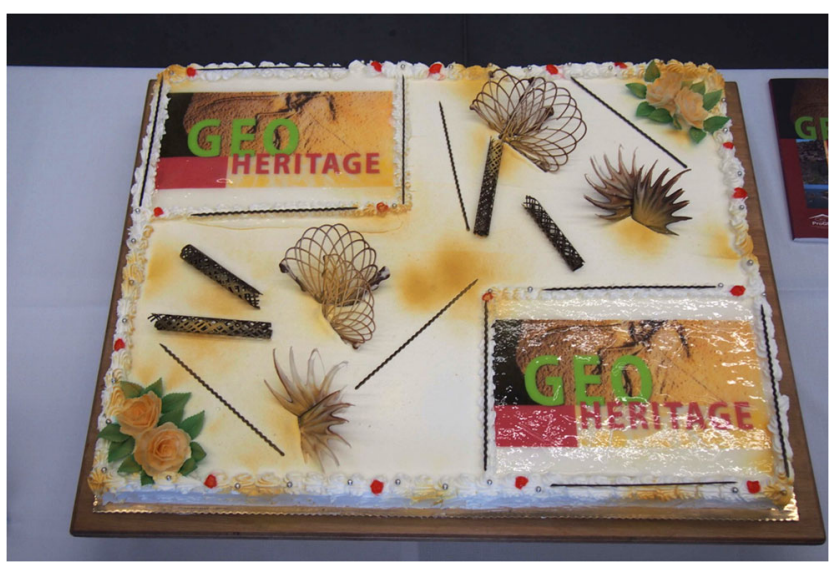

Fig. 3 The celebratory cake for the 10th Anniversary of Geoheritage. Photograph by Adrian Jarzyna

(pre-symposium field trip); and the Krzemionki Prehistoric Striped Flint Mining Region near Ostrowiec Świętokrzyski in the surroundings of the Góry Świętokrzyskie Region (post-symposium field trip). The pre-symposium filed trip was guided by Dr. hab. Jan Urban and Dr. Piotr Ziółkowski, and visits also included Ojców National Park and Wawel Hill with its Dragon Cave in Kraków (Fig. 1e), and the Nida Gypsum deposits with its famous large gypsum crystals, sedimentary processes and structures, and gypsum karst.

The post-symposium excursion through the Gorry Świętokrzyskie Region was guided by Prof. Stanisław Skompski and Dr. hab. Ewa Głowniak, and visits included Łysa Góra Range with its Cambrian quartzitic sandstones and block scree-the relict of frost weathering during the Pleistocene, Miedzianka Hill, famous for post-Variscan hydrothermal mineralization and mining Geoheritage, and Zachełmie Quarry, known for its Epi-Variscan unconformity (Fig. 1f) and the oldest described tetrapod footprints in the world in Middle Devonian dolomites. Issues discussed during the field trips included the scientific, educational, and geotouristic values of visited geosites, geological history of the area, history of mining, anthropogenic impact on the inanimate nature, and geoconservation and nature protection issues.

\section{Participation}

A total of 117 people from 25 countries took part in the Symposium (Fig. 4), including six countries lying, fully or partly, outside of Europe: Brazil, Kazakhstan, Republic of Korea, Taiwan, Turkey, and the USA (specifically Hawaii). Representatives of all Europe regional groups were present, including as follows: Russia (Russian regional group); Portugal and Spain (Southwestern Europe regional group); Denmark, Finland, Germany, Iceland, Luxemburg, Norway, Sweden, the UK (all Northwestern Europe regional group);
Czech Republic, Poland, Slovakia (Central Europe regional group); Albania, Greece, Hungary, Romania, Slovenia, Turkey (Southeastern Europe regional group). The most numerous group at the Symposium were from the Central European and Southeastern regional groups (41\% and 20\% of total number of participants, respectively). Nearly half of total number of registered participants were ProGEO members, but their number increased during the Symposium as several new members joined ProGEO.

\section{Conclusions and Results}

The Symposium enabled the exchange of information on the latest achievements in the field of geoconservation, including improving the management of geological heritage through national nature protection policy as well as the through the Sustainable Development agenda of the United Nations. ProGEO, the national institutions represented, and the Polish Committee for UNESCO supported the initiative of creating the "Geoland Kielce" in the Góry Świętokrzyskie Region-a new aspiring UNESCO Global Geopark. The conclusions of the scientific debates on geoheritage and geoconservation at the meeting have been included in the Declaration of Chęciny (http://progeo.ngo/assets/declaration_of_checiny.pdf):

\section{Declaration of Chęciny}

The participants of the 9th International Symposium of ProGEO, held at Chęciny (Poland), 25-28 June 2018, under the main theme "Geoheritage and Conservation: Modern Approaches and Applications Towards the 2030 Agenda," recognizing that geodiversity and geoheritage and their proper management are fundamental elements for the accomplishment of many of the seventeen Sustainable Development Goals proclaimed by the United Nations.

Reaffirm that:

- Both in situ and ex situ geoheritage is at risk due to human and natural factors, which justifies a need for geoconservation.

- Geoconservation policies should be established alongside nature conservation policies and implemented at all levels of public administration, from international to local. All these levels of action have their own merit, but can only be fully successful when integrated into a common strategy.

- The implementation of geoconservation actions requires a specialized knowledge and expertise. Management planning at all levels should consider the incorporation of advice and participation from geoconservationists, in particular recent graduates from universities and other institutes. 


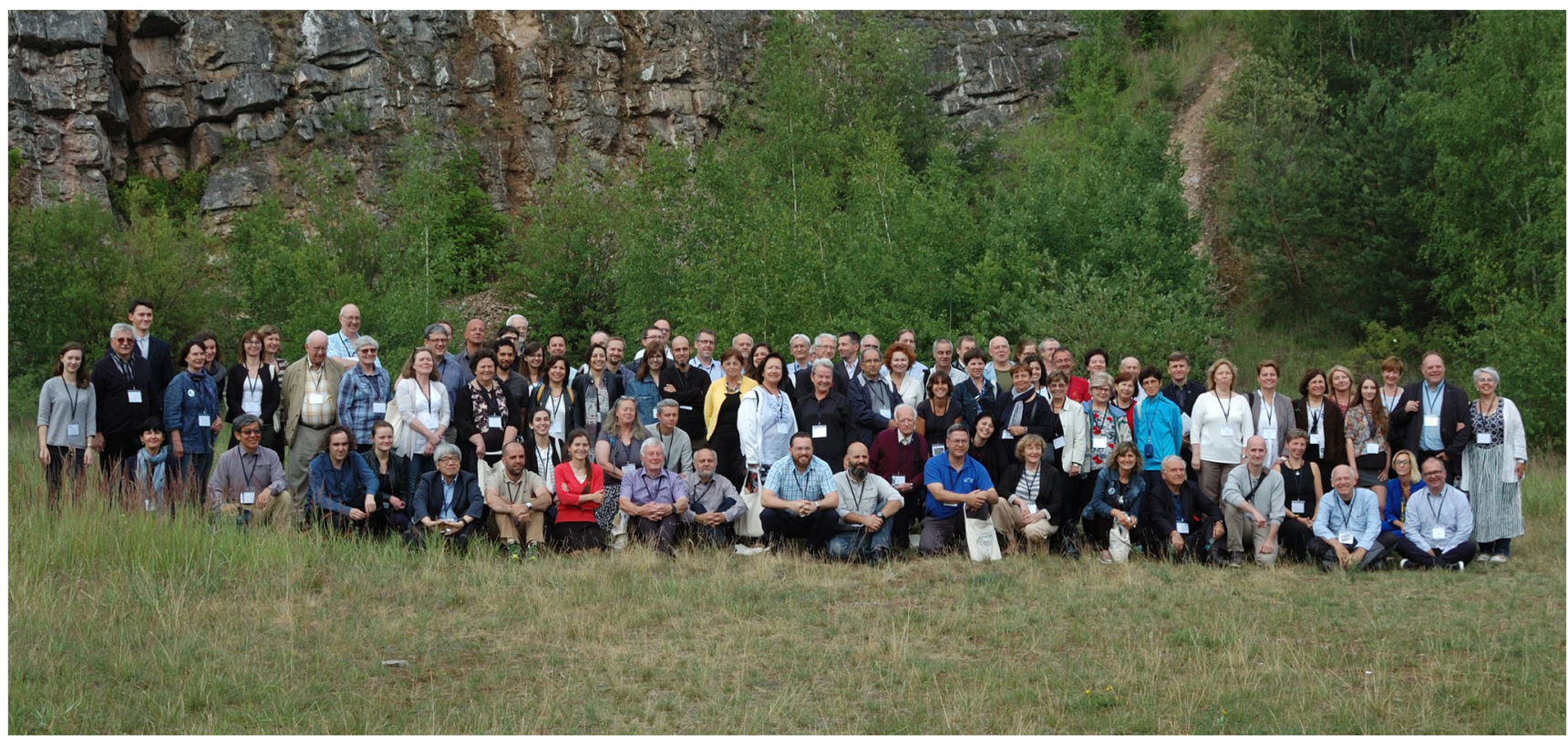

Fig. 4 The participants of the 9th ProGEO Symposium in Chęciny, Poland, 2018. Photograph by Małgorzata Bieńkowska-Wasiluk and Radosław Wasiluk

- New tools are being developed and should be used to monitor geosites and to promote an effective interpretation of geoheritage, thus contributing to increasing the awareness of society about the role of geodiversity in ecosystem services.

- Public administrations play a crucial role in guaranteeing the necessary statutory framework for geoconservation and to apply efficient conservation measures.

- Local communities play an important role in the maintenance of geoheritage, as geoparks of all levels are showing in so many countries.

\section{Afterword}

It is a great pleasure to announce the publication of this Special Volume with a wide range of papers presented at the symposium in Chęciny in 2018. I would like to thank all the reviewers who have collaborated in the preparation of this volume and congratulate the authors. Their joint work is evidence that the goals of ProGEO included in the Declaration of Chęciny have many, and still find new, supporters, and that there are still many regions that await, or need support to develop initiatives to protect their geological values. The role of geoconservation specialists and scientists is to initiate, and above all, communicate about such issues to ensure that they become visible to public administration, both at local and at international levels. This volume, appearing in a series of ProGEO Symposium volumes, is an important contribution to this goal. I wish the organizers of the 10th ProGEO Symposium to be held in Segovia, Spain, in 2020 (http://www.igme.es/patrimonio/Xprogeo2020), the same satisfaction and success that the organization of the 9th Symposium in Chęciny has given us. 